\title{
Operational Integration in Health Care versus Mass Production
}

DOI: 10.12776/QIP.V20I1.658

Inger Gamme, Geir Berg

Received 10 January 2016, Revised 09 April 2016, Accepted 19 May 2016

\begin{abstract}
Purpose: Operational integration has been studied by several authors. However, still there are many research questions to be raised.

Methodology/Approach: Two value chains have been studied within two different sectors: the health sector and the car component industry (mass producer). The research methodology is based on semi-structured interviews with selected persons from different levels within the organizations. The data was transcribed, coded and further analyzed to find enablers or disablers to operational integration in both sectors.
\end{abstract}

Findings: From this study, factors such as management commitment, colocation, and job-rotation can be seen as contributing factors in both organizations. Both experience disablers such as working as functional silos and little alignment of overall goals. Differences are seen in the greater use of job rotation within health care, while the mass producer had more mechanisms to facilitate working in cross functional teams.

Practical implication: This paper presents empirical findings of success factors and pitfalls for operational integration within the value chain of two different types of organizations. Based on this mapping, recommendations on how to achieve better operational integration will be presented.

Originality/Value of paper: The research initiative provides knowledge experiences from operational integration in two different Norwegian organizations representing two different sectors.

Category: Research paper

Keywords: collaboration; health care; integration; inter-functional; mass production 


\section{INTRODUCTION}

Today there is a constant need for improvement in any professional organization, a need driven by increasingly demands for adjustments of products or services. Both internal and external factors contribute to the requirement of more flexible and adaptable value streams. Key criteria for success are inevitably connected to how the organization meets demands from its customers, i.e. its ability to adjust to future needs and control of the process of integration between complex organizations. The automobile and health sectors face different challenges; nevertheless, they both continually strive for an adaptable and efficient value chain, aiming at delivering the best quality of service or products.

This paper will illustrate practices from interdepartmental collaboration processes within a hospital and a mass producer (MP). It focuses on principles and methods used to create a smooth and efficient interface between actors, which pitfalls they may have experienced, and possible aspects of learning for these two different organizations. The following research questions will be addressed:

- What are the enablers or hindrances to operational integration in these two value chains?

- In what ways are there similarities or differences between these two sectors?

\section{THEORY}

\subsection{Operational integration}

Working towards an optimization of the value chain, many organizations focus on the optimization of each process step, while forgetting to secure and optimize the interfaces between steps (Figure 1).



Figure 1 - Optimization of the value chain, requires focus on both process steps and interfaces

One challenge that commonly arises is the "handover of the baton" between two consecutive process steps. Factors such as a lack of documentation or systemization and the existence of functional silos or different cultures are 
possible sources of difficulty (Pagell, 2004; Basnet and Wisner, 2012). Achieving a well-managed value chain presupposes that all value creating processes act together (Stank, Keller and Daugherty, 2001) and that intraorganizational customer demand and supply capabilities are aligned and balanced. A well-managed value chain means an integrated value chain that gives the customer optimized value (Stock, Greis and Kasarda, 1999; Morash and Clinton, 1998). This will positively affect an organization's efficiencycapabilities, seen as a quicker response to changes in the customer requirements (Chen, Daugherty and Landry, 2009). Poor integration between the process steps affects the organizational performance in a negative way (Shub and Stonebraker, 2009).

Interdepartmental relations have been studied for decades, but there are still many questions to be answered (Griffin and Hauser, 1996; Childerhouse and Towill, 2011; Barratt and Barratt, 2011; Basnet and Wisner, 2012; Hayes and Wheelwright, 1984; Turkulainen and Ketokivi, 2012). Different perceptions and terms to describe the relevant phenomena are observed between authors and between disciplines. Several authors refer to the topic of integration without presenting a formal definition (Pagell, 2004). Kahn (1996) presents the following definition of integration with the mix of two constructs: information sharing and involvement:

"A process of interdepartmental interaction and interdepartmental collaboration which brings departments together into a cohesive organization."

Basnet and Wisner (2012) present another definition:

"Working together for the benefit of the company."

It can be added that participants in a value chain should share the objective of achieving a collaborative supply chain and search for common initiatives to ensure that each participant benefits from the success (Simatupang and Sridharan, 2002).

\subsection{Prerequisites for integration}

Many authors agrees that supply chain integration is valuable (Frohlich and Westbrook, 2001; Shub and Stonebraker, 2009; Pagell, 2004), but it has also been pointed out that it is not easy to achieve (Fawcett and Magnan, 2002; Bowersox, Closs and Stank, 1999; Childerhouse and Towill, 2011). In the existing research, considerable emphasis is placed on the question of why it is important to attain integration in the value chain, but few studies focus on how to achieve good integration (Basnet and Wisner, 2012; Pagell, 2004). Several contributing factors are described, such as facility and layout, job rotation, cross functional teams, amount of informal/formal communication, organizational culture, consensus on integration, and measurements and rewards (Pagell, 2004; Turkulainen, 2008; Bowersox, Closs and Stank, 1999; Basnet and Wisner, 2012). 
Culture is one of the elements that affect integration. Despite the difficulty of changing a company's culture, practitioners should try to understand how the culture affects integration (Braunscheidel, Suresh and Boisnier, 2010). Job rotation may be used as a tool to change the culture and enhance integration (Basnet and Wisner, 2012; Pagell, 2004). Another important component to acknowledge is "tacit knowledge" - knowledge which is grounded in action, commitment, and involvement. Tacit knowledge has been characterized as having an individual quality such that it is difficult to communicate and describe (Nonaka, 1994).

Many authors emphasize that management support is an important mechanism to achieve integration (Wheelwright, 1992; Daugherty, Ellinger and Gustin, 1996; Nabavizadeh, Momeni and Saidi, 2013), though there is weak evidence for this claim (Basnet and Wisner, 2012; Morash and Clinton 1998). To achieve consensus on integration it is important that top managers focus on breaking down the organizational strategy into "subtasks" (Malone and Crowston, 1994), and that all the members of an organization have frequent communication about the goals and priorities for the value chain (Pagell, 2004).

To enable better connection between two different sections, it is useful to establish common arenas for information sharing, interaction and implement visual management tools such as team board meetings (Bititci, Cocca and Ates, 2015). But the success criterion most worthy of focus is improving the quality of interaction - not just increasing the quantity - with a concomitant focus on developing relational norms interdepartmentally (Ayers et al., 2001). Standardization facilitates coordination, which is a mechanism for enhancing integration. Use of standards gives the employees a prescription for how to act and coordinates the work (Mentzer, 2004).

Many authors refer to functional silos as disablers for integration (Van Hoek and Mitchell, 2006; Turkulainen and Ketokivi, 2012; Ellinger, Keller and Hansen, 2006; Braunscheidel, Suresh and Boisnier, 2010). Organizations with hierarchic and formal structure are characterized as having vertically driven communication and a functional myopia.

Finally, the use of different reward systems for different units of the organization could have a negative impact on integration, according to (Pagell, 2004; Galbraith, 2011).

\subsection{Hospitals}

Continuously overloaded and increasing queues are a common challenge for hospitals around the world. In many hospitals, the patient flow is unpredictable, resulting in inefficiency and disorganization (Hoot and Aronsky, 2008). Continuous delays may result in poor use of resources, reduced patient care, employee dissatisfaction and increased patient mortality (Derlet and Richards, 2000). Health care and hospitals all over the world have been organized in terms of health professions and specialist fields such as surgery, internal medicine etc. 
The patient's problems are analysed individually. This is an impediment to seeing the "big picture" around the patient's needs and could contribute to problems with achieving "process flow", which again may be a reason for delays and crowded waiting rooms (Preston et al., 1999; Mainz, 1995; Mazzocato et al., 2012).

\subsection{Mass Producers}

There has been a shift in manufacturing paradigms towards supply chain integration (Muckstadt et al., 2001). Mass production is one of five production paradigms which have been utilized in recent years. In mass production, a large amount of the same product is produced (Jovane, Koren and Boër, 2003). As production volume increases, prices can be reduced and more customers may be able to buy the products. Organizations use technology to support the coordination of the employees' efforts relative to the organizational tasks and objectives. The more effectively the social and the technological systems work together, the better the organization performs (Netland et al., 2008).

For the automobile industry, common quality systems such as ISO/TS 16949:2002, which focuses on quality issues, process flow and lean solutions, have led to a more unified structure for the industry (Kymal, 2004).

\subsection{Studying Hospitals versus Mass Production}

Both hospitals and mass producers experience a demand for continuous improvements. Seim (2009) has studied similarities and differences between production companies and Operating Rooms. He claims that, among other factors, the operational challenges involve the need for quality improvements, cost reductions, maintenance or improvement in flexibility, secure customer focus and adaptability. These are similarities that make it possible to translate relevant operational management knowledge, principles and techniques between these industries. Porter (1985) claims that looking at work processes as a value chain makes it possible to consider work processes independently from environment and line of business. Even though these two industries are different from each other, they have some similarities. For instance, they both use principles and methods from total quality management (TQM). Useful comparisons can be made between these two sectors (Dahlgaard, Pettersen and Dahlgaard-Park, 2011).

\section{METHODOLOGY/APPROACH}

Two organizations were studied to find similarities or differences in enablers and disablers for integration. The organizations are quite different from each other with respect to their functions, responsibilities and societal roles. The mass producer, is located in Norway, but is part of a larger international company group. This organization produces high volumes of components for commercial 
vehicles on four continents. The second organization is a middle-sized general hospital located in the south east of Norway. The hospital is part of a network hospital organization, in which each hospital has autonomy in some defined areas, such as professional and economic issues, but also follows decisions made by the network hospital board.

Both cases are independent research initiatives made available for a $\mathrm{PhD}$ study with the aim of studying enablers of or hindrances to operational integration in value chains. The Norwegian Research Council funded both projects.

A case study is useful to understand both complex social occurrences and organizations (Eisenhardt and Graebner, 2007). A research protocol with an interview guide was prepared in advance of both studies. Semi-structured interviews were conducted to identify the degree of integration for the value chains and enablers and disablers. The same questions were asked in both organizations, and interviews were allowed to proceed at their own pace. This made it possible for the interviewees to volunteer additional information. Understanding the interviewees' experiences and how they reflect on the topic is paramount and this kind of interview can be useful in uncovering these elements (Kvale, 1997). At both organizations, interviews were performed over a period of 6 months. Each interview lasted for approximately one hour. Important aspects to consider are whether there is relevance to the research questions, whether the phenomenon to be studied may occur and whether the research is feasible and ethical (Karlsson, 2009; Yin, 2009). All the interviews were digitally recorded, transcribed verbatim and coded according to the given categories for integration (Tjora, 2011).

Table 1 gives a listing of the essential case company characteristics.

Table 1 - Company characteristics

\begin{tabular}{|c|c|c|}
\hline & Hospital & MP \\
\hline Year of study & 2013-2014 & $2012-2013$ \\
\hline Main product/service & $\begin{array}{l}\text { Patient flow for thrombolysis } \\
\text { treatment }\end{array}$ & $\begin{array}{l}\text { Car components } \\
\text { commercial vehicles }\end{array}$ \\
\hline Number of employees & 265 & 37 \\
\hline Formal interviews & 15 & 11 \\
\hline $\begin{array}{l}\text { Part of value chain } \\
\text { included }\end{array}$ & $\begin{array}{l}\text { Ambulance, emergency department, } \\
\text { X-ray, ICU, ward, internal medicine, } \\
\text { neurology. }\end{array}$ & $\begin{array}{l}\text { Injection molding, } \\
\text { assembly }\end{array}$ \\
\hline Type of informants & $\begin{array}{l}\text { Nurses, radiographer, paramedic's } \\
\text { radiographer, paramedics, attending } \\
\text { physicians, clinical nurse, specialist } \\
\text { nurses. }\end{array}$ & $\begin{array}{l}\text { Operators, production } \\
\text { manager, foreman, } \\
\text { planner, tool responsible, } \\
\text { quality technicians. }\end{array}$ \\
\hline
\end{tabular}




\section{FINDINGS AND DISCUSSION}

With focus on factors that affect integration in the value chain, the research of Pagell (2004), Basnet and Wisner (2012), Bowersox, Closs and Stank (1999) and Turkulainen (2008) has been used as a basis to categorize our findings. Factors from these researchers have been grouped to form the categories for our research (see first column of the Table 2).

Table 2 - Enablers and disablers for integration in the hospital and the MP; some may be both enablers and disablers

\begin{tabular}{|c|c|c|}
\hline $\begin{array}{l}\text { Main categories and } \\
\text { explanation }\end{array}$ & $\begin{array}{l}\text { Hospital (+) enablers, (-) } \\
\text { disablers }\end{array}$ & MP (+) enablers, $(-)$ disablers \\
\hline \multicolumn{3}{|l|}{ Culture } \\
\hline $\begin{array}{l}\text { Informal communication } \\
\text { Connecting links } \\
\text { Cross functional teams } \\
\text { Job rotation }\end{array}$ & $\begin{array}{l}\text { (+) Used to standardized } \\
\text { work } \\
(+) \text { Overall patient focus } \\
(-) \text { Lacks focus on the } \\
\text { whole value chain. } \\
(+/-) \text { Competence } \\
\text { acknowledgement makes } \\
\text { information flow better. } \\
(+/-) \text { Information flows } \\
\text { better when people know } \\
\text { each other } \\
(+/-) \text { Tacit knowledge } \\
(+) \text { Cross functional work } \\
\text { in discussion of patients. } \\
(-) \text { Job rotation: mostly } \\
\text { used at the level of } \\
\text { attending physicians }\end{array}$ & $\begin{array}{l}\text { (+) Used to standardized work } \\
(-) \text { Some lack of confidence in } \\
\text { systems } \\
(-) \text { Main focus own work } \\
\text { station, minor overall value } \\
\text { chain. } \\
(+/-) \text { Prefers verbal } \\
\text { communication more than } \\
\text { written. } \\
(+/-) \text { Informal culture } \\
(+/-) \text { Foreman connects team } \\
\text { boards, and responsible for both } \\
\text { departments } \\
(-) \text { Mainly cross functional } \\
\text { teams at higher levels } \\
(-) \text { Job rotation: no standard } \\
\text { procedure }\end{array}$ \\
\hline \multicolumn{3}{|l|}{ Vertical integration } \\
\hline & $\begin{array}{l}(+/-) \text { The culture is } \\
\text { dependent on which } \\
\text { persons and departments } \\
\text { are involved }\end{array}$ & $\begin{array}{l}\text { (+) Informal culture, little } \\
\text { hierarchy } \\
\text { (+) Department meetings each } \\
\text { week, separate days per dept. }\end{array}$ \\
\hline \multicolumn{3}{|l|}{ Formalization } \\
\hline $\begin{array}{l}\text { Policies, rules, } \\
\text { certification } \\
\text { Job descriptions } \\
\text { Standard procedures, } \\
\text { technical reports } \\
\text { Charts, information } \\
\text { process practices etc. } \\
\text { Strategic planning, } \\
\text { functional plans, } \\
\text { scheduling } \\
\text { Performance control } \\
\text { Visual systems }\end{array}$ & $\begin{array}{l}\text { (+) TQM, elements of } \\
\text { Lean established recently } \\
\text { (+) Procedures } \\
\text { (+) Overlap meetings at } \\
\text { change of shift, verbal } \\
\text { communication, telephone, } \\
\text { mail } \\
\text { (+) Some have team board } \\
\text { meetings, department } \\
\text { meetings, training in acute } \\
\text { situations } \\
\text { (+/-) Knowledge of KPI's } \\
\text { differs, some decomposed }\end{array}$ & $\begin{array}{l}\text { (+) ISO/TS 16949, ISO 14001, } \\
\text { lean } \\
\text { (+) Standardized work } \\
\text { descriptions } \\
\text { (+) Shift log, mail, verbal } \\
\text { communication etc. } \\
\text { (+) Department meetings, team } \\
\text { board meetings, shift overlap } \\
\text { meetings } \\
\text { (+/-) SAP, Excel sheets } \\
\text { (+) KPI's established, some } \\
\text { decomposed to functional } \\
\text { measures }\end{array}$ \\
\hline
\end{tabular}




\begin{tabular}{|c|c|c|}
\hline $\begin{array}{l}\text { Main categories and } \\
\text { explanation }\end{array}$ & $\begin{array}{l}\text { Hospital (+) enablers, (-) } \\
\text { disablers }\end{array}$ & MP (+) enablers, $(-)$ disablers \\
\hline & $\begin{array}{l}\text { to functional measures } \\
\text { (+) Some visual tools }\end{array}$ & $\begin{array}{l}\text { (+) Kanban, visual logistics } \\
\text { planning, visual tool status }\end{array}$ \\
\hline \multicolumn{3}{|l|}{ Facility \& Layout } \\
\hline $\begin{array}{l}\text { Plant size } \\
\text { Physical distances } \\
\text { Partitions }\end{array}$ & $\begin{array}{l}\text { (-) Large organization, } \\
\text { many process steps } \\
(-) \text { Some physical } \\
\text { distance between } \\
\text { departments, and } \\
\text { sometimes localized over } \\
\text { two different floors or } \\
\text { different buildings. } \\
(-) \text { Functional silos }\end{array}$ & $\begin{array}{l}\text { (+) Large plant, small value } \\
\text { chain } \\
\text { (+) Little physical distance. } \\
\text { (+) Intimate environment. } \\
\text { (-) Physical hindrances to } \\
\text { verbal communication } \\
\text { (-) Functional silos }\end{array}$ \\
\hline \multicolumn{3}{|l|}{ Information systems } \\
\hline $\begin{array}{l}\text { Degree of formalization of } \\
\text { information flows } \\
\text { Enhanced capacity of } \\
\text { information processing }\end{array}$ & $\begin{array}{l}\text { (+) Several systems in use } \\
\text { such as electronically } \\
\text { patient journal DIPS, mail } \\
\text { system etc. } \\
(-) \text { Some lack of trust in } \\
\text { systems }\end{array}$ & $\begin{array}{l}(+/-) \text { Several systems in use, } \\
\text { such as ERP, document } \\
\text { handling system, mail system } \\
\text { etc. } \\
(-) \text { Some lack of trust in } \\
\text { systems }\end{array}$ \\
\hline \multicolumn{3}{|l|}{ Consensus integration } \\
\hline $\begin{array}{l}\text { Functional strategies must } \\
\text { support the business } \\
\text { strategy and each other. } \\
\text { All functions support } \\
\text { business strategy and each } \\
\text { other, and all managers } \\
\text { know this is going on. }\end{array}$ & $\begin{array}{l}\text { Overall management focus } \\
\text { on economy, while } \\
\text { functional strategies focus } \\
\text { on quality }\end{array}$ & $\begin{array}{l}\text { Operators know department } \\
\text { strategy, less of company } \\
\text { strategy } \\
\text { (+) Some measures derived } \\
\text { from strategy, visual via team } \\
\text { board. } \\
\text { Operators' main focus: own } \\
\text { work }\end{array}$ \\
\hline \multicolumn{3}{|l|}{ Measurement, rewards } \\
\hline & $\begin{array}{l}(+/-) \text { Verbal } \\
\text { acknowledgments }\end{array}$ & $\begin{array}{l}(+/-) \text { Verbal acknowledgment } \\
\text { per number improvement } \\
\text { proposals }\end{array}$ \\
\hline
\end{tabular}

The findings presented under the categories in Table 2 are further discussed under each topic below.

\subsection{Culture}

In the hospital the personnel seemed to be more used to relating to systems and more faithful to structures than were the operators at the MP, and procedures were often referred to when interviewees were describing how they cooperate.

The physicians and the nurses had as a main focus the wellbeing of the patient and aimed at giving the best treatment throughout the patient flow. Still, several interviews indicated a strong functional focus, especially in certain departments. 
Several of the informants referred to professional secrecy as a reason why they were not able to follow the information concerning the patient further down the value chain.

At the MP, the informants had little overall value chain focus, and each focused mainly on his or her own process step, to the point that sharing/receiving information beyond one's own process step was perceived as unnecessary. Some claimed, "I have too much to do with my own work".

Although the hospital has a large number of systems in place for information sharing, there are examples of tacit knowledge. For example, interviewees said it was impossible to predict the number of patients that come in during a day. However, several of them had clear opinions of specific fluctuations in the rates of patient arrival.

Cultures which inspire good communication are linked to integration (Pagell, 2004). In response to the question, "When is the information flow perceived to be good?" a specialist nurse at the hospital said: "I think the information flow is good when the person I am talking with acknowledges my competence, and I acknowledge the person's competence." Another interviewee perceived the information to flow better "when you know the people you are collaborating with."

Job rotation can contribute to improving the holistic understanding of the value chain and can be an effective tool to increase integration (Basnet and Wisner, 2012). Job rotation is used to varying degrees at the hospital, primarily by the attending physicians. According to one nurse: "It could have been an advantage to have the possibility to walk in each other's shoes, since we know very little about other departments' work, when we have never been in their place." Another informant said: "job rotation is instructive, but then again it is more that has to be learnt." At the MP there had occasionally been a rotation of workers between departments, and one of the operators perceived this as giving them better knowledge of the rest of the value chain.

\subsection{Vertical integration}

According to some of the hospital interviewees who had been working in or with more than one department, the culture and structure varied in the different departments. The fact that the departments had different managers could explain the different cultures. The researchers perceived the hierarchy as larger at the hospital than at the mass producer. However, according to some of the informants at the hospital, the hierarchy has been decreased during the recent years in most of the departments. Additionally, the management is often part of the value chain, meaning that some leaders participate in clinical work. The management influences the value chain in several ways, e.g. by their budget planning, strategic choices and direction of daily management. 
The two departments at the MP were managed by the same foreman. Each department used a team board for the planning of the day's work, and the foreman was a participant in both meetings. By doing this, the foreman hoped to act as a connecting link for information flow between these two team boards and thereby achieve better integration. Nevertheless, these two departments had different cultures. Although the intention of being a part of both team meetings was to link the departments, it was perceived that the workers interacted with the foreman and not with the workers in the other department.

At both organizations it was observed that the management is actively a part of the value chain. According to Braunscheidel, Suresh and Boisnier (2010), a low degree of hierarchy positively contributes to integration, but to achieve this, management must commit and participate (Morash and Clinton, 1998; Basnet and Wisner, 2012).

\subsection{Formalization}

The MP has several standardized procedures to control processes, such as process descriptions, shift logs, shift overlap meetings, team board meetings, weekly team meetings and ERP systems. Each compartment has a team board and they also use visual systems on several occasions such as Kanban and tags for tool status. Despite all these systems, there are different perceptions of how information should flow among some of the workers.

The hospital has for several years used an electronic system called TQM. Routines and procedures related to patient treatment are developed over years, influenced partly by research, experience, legislation and professional trends. Important procedures are stored in an electronic system called EK. Over the past two years, the management has focused on increasing understanding of patient flows, through the start-up of a lean process.

Training for acute situations involves a very certain structure and a standard to be followed; there is a high degree of loyalty and discipline regarding systems and communication is very clear. This training demands a lot of resources in the hospital. In contrast, when the focus is on aspects that are important to the patient, such as waiting time and continuity of care where there is not an acute situation, the picture is quite different. Some informants state that, in less acute and life threatening situations, some choose to perform procedures in their own way.

Through study of these two organizations, it was found that both had a high degree of standardization, but the systems were designed differently. The MP used visualization systems, while the hospital used written procedures and training for acute situations. According to Mentzer (2004) this high degree of standardization could make a contribution to achieving integration, but it is recommended that it be complemented with informal interaction activities (Glouberman and Mintzberg, 2001). 


\subsection{Facility \& Layout}

In both organizations it was reported that the physical location of the departments affects their collaboration. At the MP there was an open connection between the departments, but also a minor wall. Despite this small partition, the two different departments functioned more or less as functional silos, with separate cultures and a lack of understanding of each other's daily challenges. At the hospital it might be more obvious that personnel experienced different cultures in their different parts of the value chain, since some departments were separated by as much as 8 floors.

Hayes and Wheelwright (1984) claim that a separation between subunits may reduce the degree of integration. By contrast, Pagell (2004) found little support for the idea that the size of the organization should affect the degree of integration, even though it was thought that this would be an obvious factor.

\subsection{Information systems}

The hospital had several different systems for information sharing. According to some informants too little time and "cumbersome system when dealing with difficult patients" made it difficult to document everything that should have been documented. Additionally, different departments used different systems, which did not always communicate with each other. For example, the X-ray department's system could not receive electronic referrals. The physicians had to print referrals out and deliver them physically. It was noticed during the study that several of the informants often needed to use verbal communication in addition to the electronic system in special cases.

The operators at the MP used tools such as e-mail and registration of production data in an ERP system. However, according to some of the operators, approximately $90 \%$ of the communication was verbal. It was also observed that some of the operators double-checked the systems. For example, one informant said he often checked by telephone whether the emails he had sent had been received. An explanation of why operators had mistrust of the IT systems at the MP could be, as claimed by one of the informants: "The IT strategy does not correspond with the overall company strategy." At higher levels in the organization there was more use of electronic information systems.

Gattiker (2007) and (Davenport, Harris and Cantrell, 2004) claim that information systems such as ERP systems contribute to integration. However, little support for this claim was found by Basnet and Wisner (2012).

\subsection{Consensus integration}

The employees at the hospital have an overall focus on the "customer", meaning the patient, and in some ways a focus on the overall patient flow. Despite this, some of the informants refer to an overall lack of thinking on the part of 
management. In their view, the management does not understand the clinical problems and focuses too much on economic and rational issues.

The MP had broken some of the overall goals down to functional tasks at the production level and these were visualized on the team boards. The overall strategy, though, was not that clear to all employees.

At both organizations it was seen that the correspondence between the overall strategic goals and functional tasks could be better. This is also in accordance with what Van Hoek and Mitchell (2006) found. Through an internal survey within a large European manufacturing group, they discovered internal misunderstandings and differences in both opportunities and priorities within the organization. They proposed to focus on improving the internal communication and the initiative planning process to achieve better supply chain alignment.

\subsection{Measurements rewards}

Some informants from the hospital reported that the main focus of the management was on economy, while the overall focus in the value chain was on quality. However, the governmental measures focus primarily on economy, a factor that will also affect what the management focuses on. One of the informants said: "I think the top management has their main focus on quality, but I have never heard them talking of anything else than economy." Through the recent work a focus has been placed on common goals for the value chains, but this work had not yet reached the value chain studied in this case study.

Until recently, the management at the MP has used verbal acknowledgements in accordance with the number of improvement proposals as a reward to encourage further improvements. More recently, work has been done to try to find common motivating factors for the value chain.

Both value chains are aiming towards finding a common reward system and focus, but still they face some challenges. As claimed by Cao et al. (2008), when different departments tend to have different interests and focus, it is especially important to have good overall coordination, and having differences in focus and reward systems may affect the integration negatively (Pagell, 2004).

\subsection{Summary of findiungs}

A short summary of the similarities and differences of the findings is shown in Table 3. 
Table 3 - Summary of the findings

\begin{tabular}{|c|c|c|}
\hline & Similarities & Differences \\
\hline Culture & $\begin{array}{l}\text { - Used to standardized work } \\
\text { - Tacit knowledge } \\
\text { - Some lack of overall value chain } \\
\text { focus } \\
\text { - Job rotation perceived as } \\
\text { positive }\end{array}$ & $\begin{array}{l}\text { More true to systems at the } \\
\text { hospital than in the MP. }\end{array}$ \\
\hline Vertical Integration & & $\begin{array}{l}\text { - More hierarchy at the } \\
\text { hospital than in the MP }\end{array}$ \\
\hline $\begin{array}{l}\text { Formalization and } \\
\text { standardization }\end{array}$ & - High degree of formalization & $\begin{array}{ll}\text { - } & \text { Degree of use of } \\
& \text { visualization tools in MP } \\
\text { - } & \text { Training for acute situations } \\
\text { at hospital }\end{array}$ \\
\hline Facility \& layout & - Layout challenge to integration & \\
\hline Information system & - Some mistrust of systems & $\begin{array}{l}\text { More use of information } \\
\text { systems at the hospital than } \\
\text { in the MP }\end{array}$ \\
\hline $\begin{array}{l}\text { Consensus } \\
\text { integration }\end{array}$ & & $\begin{array}{l}\text { - Insufficient connection } \\
\text { between overall strategies } \\
\text { and functional tasks }\end{array}$ \\
\hline $\begin{array}{l}\text { Measurement, } \\
\text { rewards }\end{array}$ & - Verbal acknowledgment & \\
\hline
\end{tabular}

\section{CONCLUSION}

Through two single case studies of two different organizations, the aim has been to provide a better understanding of enablers and hindrances to operational integration and the similarity or difference in these two types of value chains.

Despite the differences in the types of the two organizations, there were some findings of common enablers: both organizations had a high number of routines and standards and the employees were used to standardized work. Furthermore, in both organizations, job rotation was referred to as a contributing factor to increase integration and both companies used verbal acknowledgment as rewards.

The differences in enablers were found in the high degree of training at the hospital for acute situations, higher degree of use of visualization tools in the MP and more use of information tools directly in the value chain at the hospital.

The common disablers for integration were found to be related to culture and physical hindrances in location, tacit knowledge and difficulties in achieving good integration between overall strategies and functional tasks.

One difference in disablers was found in that the degree of hierarchy was higher at the hospital than in the MP. 
The study has focused on creating new insight into enablers and disablers for operational integration in two different types of value chains. The experiences from this study could also contribute to providing operational guidance to similar types of organizations if they want to improve their operational integration.

It is of course difficult to generalize from just two case studies, but these studies could contribute to building theory on the topic. Further research should focus on achieving more information on the enablers and disabler for operational integration, by doing a study of more organizations.

\section{REFERENCES}

Ayers, D.J., Gordon, G.L. and Schoenbachler, D.D., 2001. Integration And New Product Development Success: The Role Of Formal And Informal Controls. Journal of applied business research, 17(2), pp.133-148.

Barratt, M. and Barratt, R., 2011. Exploring internal and external supply chain linkages: Evidence from the field. Journal of Operations Management, 29, pp.514-528.

Basnet, C. \& Wisner, J., 2012. Nurturing Internal Supply Chain Integration. Operations and Supply Chain Management, 5, pp.27-41.

Bititci, U., Cocca, P. and Ates, A., 2015. Impact of visual performance management systems on the performance management practices of organisations. International Journal of Production Research, 54(6), pp.1-23.

Bowersox, D.J., Closs, D.J. and Stank, T.P., 1999. 21st century logistics: making supply chain integration a reality. Michigan State University, Council of Logistics Management.

Braunscheidel, M. J., Suresh, N. C. and Boisnier, A. D. 2010. Investigating the impact of organizational culture on supply chain integration. Human Resource Management, 49(5), pp.883-911.

Cao, N., Zhang, Z., To, K.M. and Ng, K.P., 2008. How are supply chains coordinated?: An empirical observation in textile-apparel businesses. Journal of fashion marketing and management, 12(3), pp.384-397.

Chen, H., Daugherty, P.J. and Landry, T.D., 2009. Supply chain process integration: a theoretical framework. Journal of Business Logistics, 30(2), pp.2746.

Childerhouse, P. and Towill, D. R. 2011. Arcs of supply chain integration. International Journal of Production Research, 49(24), pp.7441-7468.

Dahlgaard, J.J., Pettersen, J. and Dahlgaard-Park, S.M., 2011. Quality and lean health care: A system for assessing and improving the health of healthcare organisations. Total Quality Management \& Business Excellence, 22(6), pp.673689. 
Daugherty, P.J., Ellinger, A. E. and Gustin, C.M., 1996. Integrated logistics: achieving logistics performance improvements. Supply Chain Management: An International Journal, 1(3), pp.25-33.

Davenport, T.H., Harris, J.G. and Cantrell, S., 2004. Enterprise systems and ongoing process change. Business Process Management Journal, 10(1), pp.1626.

Derlet, R. W. and Richards, J. R. 2000. Overcrowding in the nation's emergency departments: complex causes and disturbing effects. Annals of emergency medicine, 35(1), pp.63-68.

Eisenhardt, K.M. and Graebner, M.E., 2007. Theory Building from Cases: Opportunities and Challenges. The Academy of Management Journal, 50(1), pp.25-32.

Ellinger, A.E., Keller, S.B. and Hansen, J.D., 2006. Bridging the divide between logistics and marketing: facilitating collaborative behavior. Journal of business logistics, 27(2), pp.1-27.

Fawcett, S.E. and Magnan, G.M., 2002. The rhetoric and reality of supply chain integration. International Journal of Physical Distribution \& Logistics Management, 32(5), 339-361.

Frohlich, M.T. and Westbrook, R., 2001. Arcs of integration: an international study of supply chain strategies. Journal of Operations Management, 19(2), pp.185-200.

Galbraith, J. R., 2011. The star model. [pdf] Retrieved from http://www. jaygalbraith.com/pdfs/Star Model.pdf.

Gattiker, T.F., 2007. Enterprise resource planning (ERP) systems and the manufacturing-marketing interface: an information-processing theory view. International Journal of Production Research, 45(13), pp.2895-2917.

Glouberman, S. and Mintzberg, H., 2001. Managing the care of health and the cure of disease--Part II: Integration. Health Care Management Review, 26(1), pp.56-69.

Griffin, A. and Hauser, J.R., 1996. Integrating R\&D and marketing: a review and analysis of the literature. Journal of product innovation management, 13(3), pp.191-215.

Hayes, R.H. and Wheelwright, S.C., 1984. Restoring our competitive edge: competing through manufacturing, New York, NY: John Wiley \& Sons.

Hoot, N.R. and Aronsky, D., 2008. Systematic review of emergency department crowding: causes, effects, and solutions. Annals of emergency medicine, 52(2), pp.126-136.e1. 
Jovane, F., Koren, Y. and Boër, C.R., 2003. Present and Future of Flexible Automation: Towards New Paradigms. CIRP Annals - Manufacturing Technology, 52(2), pp.543-560.

Kahn, K.B., 1996. Interdepartmental integration: a definition with implications for product development performance. Journal of product innovation management, 13(2), pp.137-151.

Karlsson, C., 2009. Researching Operations Management, Taylor \& Francis.

Kvale, S., 1997. Det kvalitative forskningsintervju. Oslo: Ad Notam Gyldendahl.

Kymal, C., 2004. The ISO/TS 16949 Implementation Guide: Gaining Value from Your ISO/TS 16949 Implementation, Paton Professional.

Mainz, J., 1995. Problem identification and quality assessment in health care. Theory, methods, results. København: Munksgaard.

Malone, T.W. and Crowston, K., 1994. The interdisciplinary study of coordination. ACM Computing Surveys, 26(1), pp.87-119.

Mazzocato, P., Holden, R.J., Brommels, M., Aronsson, H., Bäckman, U., Elg, M. and Thor, J., 2012. How does lean work in emergency care? A case study of a lean-inspired intervention at the Astrid Lindgren Children's hospital, Stockholm, Sweden. BMC Health Services Research, 12(28), pp.1-13.

Mentzer, J.T., 2004. Fundamentals of supply chain management: twelve drivers of competitive advantage, Sage publications.

Morash, E.A. and Clinton, S.R., 1998. Supply chain integration: customer value through collaborative closeness versus operational excellence. Journal of Marketing Theory and Practice, 6(4), pp.104-120.

Muckstadt, J.A., Murray, D.H., Rappold, J.A. and Collins, D.E., 2001. Guidelines for Collaborative Supply Chain System Design and Operation. Information Systems Frontiers, 3(4), pp.427-427.

Nabavizadeh, R., Momeni, M. and Saidi, S. S. 2013. The Impact of Aligned Rewards and Senior Manager Attitudes on Conflict and Collaboration between Sales and Marketing in JahanBehbood Pharmaceutical Co. International Research Journal of Applied and Basic Sciences, 5(6), pp.756-761.

Netland, T.H., Knutstad, G., Buvik, M. and Skjelstad, L., 2008. The New Importance Of Socio-Technical Systems Research On High-Tech Production Systems. Paper submitted to HOPS, Lausanne, Switzerland.

Nonaka, I., 1994. A dynamic theory of organizational knowledge creation. Organization science, 5(1), pp.14-37.

Pagell, M., 2004. Understanding the factors that enable and inhibit the integration of operations, purchasing and logistics. Journal of Operations Management, 22(5), pp.459-487. 
Porter, M.E., 1985. Competitive advantage: creating and sustaining superior performance. New York: Free Press.

Preston, C., Cheater, F., Baker, R. and Hearnshaw, H., 1999. Left in limbo: patients' views on care across the primary/secondary interface. Quality in Health Care, 8(1), pp.16-21.

Seim, A.R., 2009. Process Analysis and Monitoring in Complex Perioperative Environments: Health Operations Management. Ph. D. Norwegian University of Science and Technology.

Shub, A.N. and Stonebraker, P.W., 2009. The human impact on supply chains: evaluating the importance of "soft" areas on integration and performance. Supply Chain Management: An International Journal, 14(1), pp.31-40.

Simatupang, T.M. and Sridharan, R., 2002. The collaborative supply chain. The International Journal of Logistics Management, 13(1), pp.15-30.

Stank, T.P., Keller, S.B. and Daugherty, P.J., 2001. Supply chain collaboration and logistical service performance. Journal of Business Logistics, 22(1), pp.2948.

Stock, G.N., Greis, N.P. and Kasarda, J.D., 1999. Logistics, strategy and structure: a conceptual framework. International Journal of Physical Distribution \& Logistics Management, 29(4), pp.224-239.

Tjora, A. 2011. Kvalitative forskningsmetoder i praksis. Gyldendal Akademisk.

Turkulainen, V., 2008. Managing cross-functional interdependencies-the contingent value of integration. Ph. D., Teknillinen korkeakoulu.

Turkulainen, V. and Ketokivi, M., 2012. Cross-functional integration and performance: what are the real benefits? International Journal of Operations \& Production Management, 32(4), pp.447-467.

Van Hoek, R.I. and Mitchell, A., 2006. The challenge of internal misalignment. International Journal of Logistics, 9(3), pp.269-281.

Wheelwright, S.C., 1992. Revolutionizing product development: quantum leaps in speed, efficiency, and quality. Simon and Schuster.

Yin, R.K., 2009. Case Study Research, Design and Methods. Sage Publications Inc.

\section{ABOUT THE AUTHORS}

Inger Gamme, Ph.D. Candidate, Gjøvik University College/ NTNU, inger.gamme@hig.no, Teknologiveien 22, 2815 Gjøvik, Norway

Geir Berg, Dr. Public Health, MNSc, RN, Innlandet Hospital Trust Lillehammer, geir.berg@sykehuset-innlandet.no, Postboks 104, 2381 Brumunddal, Norway 